\title{
Sources of State Revenue and State Effectiveness: The Nigerian Experience
}

\author{
Ebi Bassey Okon ${ }^{1} \&$ Nyong Saviour Okon ${ }^{1}$ \\ ${ }^{1}$ Department of Economics, University of Calabar, Calabar, Nigeria \\ Correspondence: Ebi Bassey Okon, Department of Economics, University of Calabar, Calabar, Nigeria. Tel: \\ 234-703-811-6912.
}

Received: April 22, 2020

Accepted: May 27, 2020

Online Published: December 24, 2020

doi:10.5430/ijfr.v12n1p111

URL: https://doi.org/10.5430/ijfr.v12n1p111

\begin{abstract}
Ineffectiveness of states has been linked to poor fiscal-social contract between states and her citizens which is a consequence of how states raise her revenues. Hence, this paper examines the relative impacts of earned and unearned revenues on different measures of state effectiveness in terms of provision of basic public goods and development of economic and political institutions in Nigeria over the period 1996 to 2018, using Autoregressive Distributive Lag (ARDL) estimation technique. The paper found that, on one hand, an increase in earned revenue instigates improvement in provision of health care, while increase in unearned revenue had no significant impact on provision of health. On the other hand, a one-percent (1\%) increase in earned revenue had a greater impact on educational enrollment than a $1 \%$ increase in unearned revenue. Increase in earned revenue increases state effectiveness while increase in unearned revenue reduces state effectiveness. The paper concludes that, the effectiveness of Nigerian government in provision of basic public goods and development of strong economic and political institutions might improve if government increases their financial resources through taxes than increase in oil revenue.
\end{abstract}

Keywords: revenues, fiscal-social contract, state effectiveness, Nigeria

JEL Classification: $\mathrm{H} 2, \mathrm{H} 3, \mathrm{H} 4$

\section{Introduction}

In World Bank Report (2005), ineffective or failed states are described as poorly performing countries, characterized by weak policies, institutions and failure to provide adequate public goods and services to their citizens. There is also a strong foundational consensus that effective state is important for development and human wellbeing. Hence, the current concern to scholars is on how effectiveness of the state are established. On this, fiscal-social contract (fiscal sociology) has become a more obviously crucial element in effective state development. Development of an effective state can be influenced by how the state raises its revenue. How state raises revenue may be classified into earned and unearned state revenues. States earn their revenue if they work closely with their citizens in order to generate it. This implies exchange between citizens and the state. Wherein, the state provides basic infrastructures in return for tax paid by the citizens. Alternatively, unearned revenue derived from uncommon sources, requires little interface between the state and the citizenry. In other ways, provision of important public goods such as education and health as well as strong institutional qualities such as rule of law and control of corruption tend to be weaker in rentier states, where revenue is received and not earned. Specifically, States (rulers) that rely upon earned income through taxes are likely to be more effective politically and institutionally (effective state). On the other hand, if the state relies primarily on unearned revenue, in this context, the revenue supporting the state comes from uncommon natural resources like crude oil, such a state is likely to be ineffective in provision of basic public goods and development of strong economic and political institutions (Lehne, Mo and Plekhanov, 2014; Paler, 2013; Self and Grabowski, 2006; Islam and Montenegro, 2002).

This paper tested this prediction by comparing the relative effects of conceivably increases in total tax revenue (earned revenue) and total non-tax revenue (received or unearned revenue) on state effectiveness and performance in the context of Nigeria using yearly data over the period 1996 to 2018 . The time frame is selected due to the fact that data on country institutional effectiveness are available from 1996. The study is motivated to test this prediction in Nigeria given the fact that Nigerian government have access to several sources of revenue, both earned (tax revenue) 
and unearned (oil revenues) and the fact that Nigeria is heavily dependent on revenue from unearned sources (oil-revenue), rather than on internally-generated tax revenue. Precisely, revenues from oil constituted over $70 \%$ of the Nigeria's total revenue between 1996 and 2017 (Central Bank of Nigeria [CBN], 2017; Ebi, 2018; Ebi \& Ayodele, 2016; Ebi \& Aladejare, 2016).

Furthermore, indicators of state effectiveness like provision of basic public goods such as education and health which measures the wellbeing of the people as well as economic and political institutions have all deteriorated in most years since Nigeria began depending heavily on unearned revenue from oil. For instance, the report released by UNICEF, the World Health Organization, the World Bank and the Population Division of UNDESA, which make up the Inter-Agency Group for Child Mortality Estimation (IGME), showed that, Nigeria was third country with the highest infant mortality rate in the world. This report also indicated Nigeria as the second largest country with under-five and maternal mortality rate in the world (WHO 2017).

According to the Report of Multiple Indicator Cluster Survey conducted by National Bureau of Statistics (NBS) and United Nations Children's Fund (UNICEF) between 2016-2017, infant mortality rate was estimated to be 70 per 1,000 live births in Nigeria. This entails that 1 in every 15 livebirths in Nigeria die before their first birthday (NBS 2018).

In terms of education, it is estimated that, about $40 \%$ of Nigerian children aged 6 to 11 do not attend any primary school. About 4.7 million children of primary school age are still out of school. Many of those enrolled in school do not complete the primary school cycle. About $30 \%$ of pupils drop out of primary school and only 54\% transit to secondary schools. The prospects of Nigeria achieving Education for all still remain feeble (NBS, 2018; Ebi and Ubi, 2017).

Institutional qualities have also deteriorated as Nigeria is being listed among 31 most corrupt countries in the world vis-à-vis a weak state. Specifically, Nigeria occupied $144^{\text {th }}$ position in the list of least corrupt nation out of 175 countries in 2018. According to the 2018 Corruption Perceptions Index reported by Transparency International, average Corruption Rank in Nigeria from 1996 to 2018, was 121 with an all-time highest of 152 in 2005 and a record lowest of 52 in 1997 (Transparency International, 2018).

In terms of governance indicators proxy by government effectiveness index which comprises, among other things, the capacity of the state to effectively formulate and implement sound policies; and the respect of citizens and the state for the institutions that govern economic and social interactions among them. The Worldwide Governance Indicators (WGI, 2018) showed that, Nigeria scored -0.92 in 1996 and was ranked 18 while the value deteriorated to -1.09 in 2016 with a rank of 12.

It is important to note that the chosen indicators/measures of effectiveness in provision of basic infrastructure (health and education) and the government effectiveness index for the effectiveness of economic and political institutions are based on their importance and availability of data. For instance, the end point of state effectiveness is the wellbeing of the people. Health and education are indispensable in the determination of the wellbeing of the people.

\section{Theoretical and Literature Review}

This section reviewed theories and empirical studies on the relationship between sources of revenue and state effectiveness as follows.

\subsection{Theoretical Literature}

The underpinning theory for this work is the Fiscal-social Contract Theory otherwise known as State-society Relations Theory. The theory assumptions that, there is a relationship between the dependence of governments on levied taxes from the public and the existence of some kind of binding constraints on governments that is essential for the formation of an effective state. Concisely, relative to rentier states, tax states tend to have more accountable representative and effective government. That, a rentier state depends largely on unearned revenue, where the revenue is received with little organizational or political effort on the part of the state, and especially little such effort in relation to their domestic populations (Moore, 2004). Whereas, tax states depend mostly on earned revenue that places considerable organizational, bureaucratic, and political demands on the state apparatus to collect.

As pointed out by Moore (2004), the fiscal-social contract paradigm proves its worth in the study of comparative state formation and effectiveness. Variations in the sources of state revenue to a significant degree explain differences in the form of states and her effectiveness, and in how they relate to citizens.

Relative to dependence on tax based revenue, the dependence of a state on non-tax (unearned) revenue tends to generate the following basic consequences: 
(i) Autonomy from citizens. Where the state and its agents have a "guaranteed" source of income in the form of resource rents that makes them independent of potential taxpayers. Such a state is not likely to interface much with the citizens or allow the populace to have any sizeable democratic influence over the state. They will not use their scarce administrative resources to promote broad economic development when the state can feed itself from mineral revenues. It is more efficient for a rentier state to use some revenue to buy off those citizens likely to cause trouble and more of it to support a powerful army and intelligence apparatus that will keep others in line.

(ii) Non-transparency in public expenditure. In most rentier states where revenues are received than earned, it is relatively easier for revenue and expenditure to be hidden from the public. The official budget may represent a mere shadow of the true fiscal situation. Taking Nigeria as an example, The Nigeria National Petroleum Cooperation (NNPC) is more or less fiscal and political state of her own within Nigerian state, usually with the president as minister of petroleum.

(iii) Ineffective public bureaucracy. There is usually little incentive to establish an efficient public bureaucracy in rentier states. This because, the task of raising revenue from the mineral facilities requires few specialists and these may be imported to make them easily controllable. It may not be necessary to establish the kind of efficient meritocratic public bureaucracy that is required to manage a complex and efficient tax system or to establish the control mechanisms and public-service values needed to protect against the worst abuses in tax collection like in tax states. In the rentier state, jobs are mostly given based on patronage and for direct political reasons (Moore, 2004).

\subsection{Empirical Issues on Sources of Revenues and State Effectiveness}

Generally, very few empirical literatures exit on how different sources of state revenues can influence state effectiveness and to the best of our knowledge, non-exist in the context of Nigeria. The few literatures are presented here.

Martinez (2014) employed panel data from Colombian municipalities for the period 2005 to 2011 to test whether increase in taxation had a greater impact on government effectiveness in providing public goods than increase in non-tax revenue through their opposite effects on citizens' willingness or ability to hold the government accountable. His findings showed that, the impact of a \$1 increase in tax revenue on educational enrollment was twice as large as the impact of a \$4 increase in oil/coal revenues on educational enrollment. The findings aligned with that of Gadenne (2014) who found that the quantity and quality of educational infrastructure in Brazilian municipalities is positively affected by local tax revenue while additional non-tax revenue have no effect; as well as Zhuravskaya (2000) who found that public good provision is better in Russian cities where increases in revenue are from taxes.

Lehne, et al, (2014) examined the determinants of the quality of economic institutions such as rule of law and control of corruption in a large sample of countries between 1996 and 2011. Their overall findings suggested that the impact of commodity wealth (unearned revenue) on qualities of economic institutions such as control of corruption was negative.

Moore (2004) investigates the extent to which the quality of governance in contemporary developing countries might improve if states were more dependent for their financial resources on domestic tax payers. Using a proposition from fiscal sociology, he found that sources of state revenue had a major impact on patterns of state formation. That the proposition was strong and convincing in the context of western European history and comparisons among contemporary states.

There is also evidence supporting the idea that taxation increases voters' willingness to hold the government accountable. Paler (2013) found that participants in lab experiments are more willing to engage in costly punishment of a misbehaving government when the source of revenue is taxation than when it is external.

Besley and Persson (2011) provide a theoretical account of how external revenue provides low incentives to improve the ability to tax, which has a detrimental effect on growth. Ross $(2001,2004)$ provides evidence in support of a rentier effect, according to which the availability of external revenue leads to a political equilibrium with low taxation and low accountability. Bauer (1972) argues that one of the reasons for the ineffectiveness of development assistance is precisely because it allows governments to loosen the fiscal contract with voters. A similar point has been made in the context of the natural resource curse (Frankel, 2012).

Easterly and Levine (2003) examined the influences of some selected factors including mineral endowment on institutional quality and the quality of state decision making. They found that settler transience and latitude variables are strongly and positively related to institutional quality. While minerals endowment impacted negatively on institution and quality of state decision making. 
Notable Economists like Barro (1999); Sala-i-Martin and Subramanian (2003); Ross (2001); and Isham et al (2005) had detected that, natural resources endowment causes the quality of institution to decay and this in turn leads to poor economic performance. There is a political version of the above observation that argues that nations that are heavily dependent upon natural resources in terms of revenue generation are development failures and are more likely to be subjected to violence/civil war, as well as a general situation in which defective institutional structures persist. There are two mechanisms by which this process is thought to work. The first is the looting mechanism developed in the work of Collier (1998). The second mechanism is that conflicts over the distribution of rents often lead to crises. There is some empirical evidence to support these ideas. The work of Collier (1998) indicates that dependence on oil and/or minerals radically increases the chance of civil war and existence of a weak state. While Adsera, Boix, \& Payne (2003) maintained that, natural resource abundance can lead to a weakening of democratic institutions as well as economic ones. According to them, in resource-rich countries the ruling elites are likely to be particularly opposed to democratization and a strengthening of economic institutions because stronger institutions, such as rule of law or control of corruption enforces checks and balances that makes it difficult for the ruling elites to appropriate natural resource rents.

Ferejohn \& Rosenbluth (2010), examined the relationship between warfare and state development in medieval Japan. They argue that vulnerable lowlands farmers were willing to pay taxes to local warlords in exchange for security. As fear of violence became widespread, this willingness grew, enabling successful warlords to afford larger armies. The final result of the process was state consolidation throughout Japan by 1600.

Dincecco (2015) Using a trend analysis highlighted the importance of political reforms that promotes both state strength and efficiency. Dincecco (2015) found that during the period that Guatemalan government collected revenues equivalent to less than 10 percent of GDP, Police, prosecutors, and court officials were under-funded and Guatemala had one of the world's highest murder rates. He concluded that National governments must have the political and administrative capacity to raise enough revenue through taxes in order to provide adequate basic public services and strong institutional quality. At the same time, tax payers/citizens must participate and have a voice in the political process and fiscal decisions making.

As stated earlier, very few empirical literatures exit on how different sources of state revenues can influence state effectiveness with none in the context of Nigeria. Hence, the contribution of this paper to the exiting literature on this subject matter lies not only on the fact that this relationship is tested in the context of Nigeria to the fact that more measures of state effectiveness namely: infant mortality rate and basic education enrollment which measures state effectiveness in provision of health and educational services vis-à-vis wellbeing of the people and the used of government effectiveness index which measures the effectiveness of state economic and political institutions. None of the studies reviewed employed this wide range of measures of state effectiveness in a single study.

\section{Research Methodology}

The design adopted in this study was an ex post facto (after the fact) design. This is because the events had already taken place before the investigation is carried out. The choice of this method is made because we have no control of the independent variables and inferences about the relationship among the variables. The quantitative nature of the research requires an empirical analysis aimed at testing the hypothesis that an increase in tax revenue has a larger positive effect on components of state effectiveness than an increase in unearned revenue such as non-tax revenue in Nigeria.

\section{Model Specification}

The models are anchored on Fiscal-Social Contract and Rentier State Theories which emphasize that there exists a causal connection between the dependence of governments on levied taxes from public and the existence of some kind of binding constraints on governments that is essential for the formation of an effective state.

Indicators of state effectiveness which constitute dependent variables in this study include: infant mortality rate (IMR) and secondary school education enrollment (SSEE) which measures state effectiveness in provision of health and education vis-à-vis wellbeing of the people; and government effectiveness index (GOVEFF) which measures the effectiveness of economic and political institutions in Nigeria. Total tax revenue or earned revenues (TREV) and total non-tax revenue or unearned revenue (NONTREV) constitutes the primary (independent) variables and policy variables of interest.

The relationship between various indicators of state effectiveness and sources of revenues are specified in the following equations: 


\subsection{Sources of Revenue and Provision of Health Care Equation}

While the anchored theories above provide justification for the policy variables as per the relationship between sources of revenues (Total tax revenue (TREV) and total non-tax revenue (NONTREV)) and state effectiveness in provision of public health proxy by infant mortality rate (IMR), scholars have also reasoned that rapidly growing countries and educated people are likely to afford better quality of health (Self and Grabowski, 2006). Hence, control variable such as the growth rate of GDP per capita (PCGDPR) is added.

Accordingly, the paper specifies that:

$$
\mathrm{IMR}=\mathrm{f}\left(\mathrm{TREV}, \text { NONTREV }, \text { PCGDPR, } \mathrm{U}_{1}\right)
$$

Econometrically, equation 1a would be

$$
\text { IMR }=\mathrm{a}_{0}+\mathrm{a}_{1} \text { TREV }+\mathrm{a}_{2} \text { NONTREV }+\mathrm{a}_{3} \text { PCGDPR }+\mathrm{u}_{1}
$$

Where:

IMR $=$ Infant Mortality rate per 1,000 live births as proxy for state effectiveness in provision of health

TREV = Total tax revenue in Naira

NONTREV $=$ Total nontax revenue in Naira

PCGDP $=$ Per capita income in Naira

$\mathrm{U}_{1}=$ Error term

$\mathrm{a}_{0}=$ Constant term

$a_{1}$ to $a_{3}$ are the coefficients of the respective explanatory variables to be estimated

The a priori expectations are that $\mathrm{a}_{0}, \mathrm{a}_{1}$, and $\mathrm{a}_{3}<0$, while $\mathrm{a}_{2}>0$

4.2 Sources of Revenue and Provision of Basic Education Equation

Following the same propositions in 3.2.1, the paper specifies that:

$$
\mathrm{SSEE}=\mathrm{f}\left(\mathrm{TREV}, \text { NONREV }, \text { PCGDPR, } \mathrm{U}_{2}\right)
$$

Econometrically, equation 3.2a would be

$$
\text { SSEE }=b_{0}+b_{1} \text { TREV }+b_{2} \text { NONTREV }+b_{3} \text { PCGDPR }+u_{2}
$$

Where:

SSESS $=$ Secondary School Education Enrollment which measures state effectiveness in provision of education

TREV, NONTREV and PCGDPR are as defined earlier

$\mathrm{U}_{2}=$ Error term

$\mathrm{b}_{0}=$ Constant term

$b_{1}$ to $b_{3}$ are the coefficients of the respective explanatory variables to be estimated

The apriori expectations is that $\mathrm{b}_{0}, \mathrm{~b}_{1}$ and $\mathrm{b}_{3}>0$, while $\mathrm{b}_{2}<0$

\subsection{Sources of Revenue and Government Effectiveness Equation}

The model is also anchored on Fiscal-Social Contract Theory and rentier state hypothesis which emphasize that there exists a causal connection between sources of revenues (Total tax revenue (TREV) and total non-tax revenue (NONTREV)) and state effectiveness in terms of level of government effectiveness. Rapidly growing countries and educated people are also better able to afford better quality of institutions such as low corruption.

Accordingly, the paper specifies that:

$$
\text { GOVEFF }=\mathrm{f}\left(\mathrm{TREV}, \text { OILREV }, \text { PCGDP, } \mathrm{U}_{3}\right)
$$

Econometrically, equation 3.3a would be

$$
\text { GOVEFF }=\mathrm{c}_{0}+\mathrm{c}_{1} \text { TREV }+\mathrm{c}_{2} \text { NONTREV }+\mathrm{c}_{3} \text { PCGDP }+\mathrm{u}_{3}
$$

Where:

GOVEFF $=$ Government effectiveness index

TREV, NONTREV and PCGDPR are as defined earlier 
$\mathrm{U}_{3}=$ Error term

$\mathrm{c}_{0}=$ Constant term

$c_{1}$ to $c_{4}$ are the coefficients of the respective explanatory variables to be estimated

The apriori expectations is that $\mathrm{c}_{0}, \mathrm{c}_{1}$, and $\mathrm{c}_{3}>0$, while $\mathrm{c}_{2}<0$.

\subsection{Description and Measurement of Variables}

Government effectiveness (GOVEFF): This is an important proxy for institutional quality. It mirrors the perceptions of the quality of civil service and the degree of its independence from political pressures, the quality of policy formulation and its implementation, and the credibility of government's commitment to such policies. The index also measures the manner in which power is exercised in the management of a country's economic and social resources including external debt for sustainable economic development. Government effective index ranges from -2.5 (weak) to 2.5 (strong) government performance. Effective governance is an indication of high quality institutions and has positive relationship with economic growth and development.

Infant Mortality Rate: Measure the effectiveness of the state in providing health service. Infant Mortality rate per 1,000 live births as proxy for state effectiveness in provision of health is used here. The lower the rare the more effective the state.

Per capita (PCGDPR): Is the growth rate of real GDP divided by the population. Rapidly growing countries and educated population are likely to enhance better quality institutions and hence effective state.

Tax revenue (TREV): Tax revenues are revenues generated from taxation and utilized for the provision of public goods and services such as basic health care and education. It is an independent variable in this study and is expected to have positive relationship with the dependent variables.

Non-tax revenue (NONTREV): The non-tax revenues are revenues generated from oil and grants and utilized for the provision of basic amenities such as basic health care and education. It is an independent variable in this study and is expected to have negative relationship with the dependent variables.

\subsection{Data}

The empirical exercise required six main secondary time series data namely: Total tax revenue (TREV), total non-tax revenue (NONTREV) for sources of state revenues. Infant mortality rate (IMR), secondary school education enrollment (SSEE) and government effectiveness (GOVEFF), represents the effectiveness of state. While growth rate of GDP per capita (PCGDPR) is a control variable. These data were obtained from secondary sources such as the World Bank development indicators, Central Bank of Nigeria (CBN) annual account statements and reports and World Bank Governance Indicators.

\subsection{Model Estimation Procedures}

The study utilized several estimation procedures in arriving at the final estimation stage. Hence, unit root test, the co-integration tests and ARDL estimation techniques were employed.

\section{Results and Discussion of Findings}

\subsection{Unit Root Test Results}

The Augmented Dickey Fuller unit root test was conducted to examine the stationarity condition of the variables. As indicated in table 1, TREV, IMR and PCGDPR were stationary at levels in the ADF test. In other words, the variables are integrated of order zero (i.e., I (0)). Conversely, NONTREV, SSEE and GOVEFF became stationary after first differencing. The aforementioned variables are therefore integrated of order one i.e., they are I (1).

Where some of the variables are I (0) while others are I (1) suggest the problem of unit root in the equations. It becomes imperative to perform co-integration tests to determine the presence of equilibrium relationship amongst the variables in each equation. The paper adopts the ARDL bound testing technique for co-integration, as the variables are integrated of diverse orders (i.e., order zero and order one). 
Table 1. ADF unit root test results

\begin{tabular}{llll}
\hline Variables & ADF Level & $\mathbf{1}^{\text {st }}$ Difference & Order of integration \\
\hline IMR & $-4.714401^{*}$ & - & $\mathrm{I}(0)$ \\
\hline SSEE & -1.481115 & $-5.475925^{*}$ & $\mathrm{I}(1)$ \\
\hline GOVEFF & -1.911136 & $-7.421029^{*}$ & $\mathrm{I}(0)$ \\
\hline TREV & $-3.663418^{* *}$ & - & $\mathrm{I}(1)$ \\
\hline NONTREV & -1.608127 & $-3.985657^{*}$ & $\mathrm{I}(1)$ \\
\hline PCGDPR & $-3.682950^{* *}$ & - & $\mathrm{I}(0)$ \\
\hline
\end{tabular}

Source: Researcher's compilation (2019)

Note: Mackinnon critical values for ADF at 1, 5 and $10 \%$ levels are $-3.80,-3.02$ and -2.65 respectively.

$*, * *$ and $* * *$ means significant at 1,5 and 10 respectively.

\subsection{Co-integration Test Results}

From the bound testing result reported in Table2, long run relationship exists amongst the variables in the three estimated equations, given that the values of the F-statistic are greater than the critical values at five per cent level in both the upper and the lower bounds. Therefore, the null hypothesis of absence of co-integration is rejected, while the study proceeds to estimate the long run coefficient of each of the equations.

Table 2. Co-integration test results

\begin{tabular}{|c|c|c|c|c|c|}
\hline & \multicolumn{5}{|c|}{$5 \%$ critical value } \\
\hline Equations & $\mathbf{K}$ & F-Stat. & I (0) & I (1) & Outcome \\
\hline IMR (TREV, NONTREV, PCGDPR) & & 3 & 9.35 & 3.23 & 4.35 \\
\hline \multicolumn{6}{|l|}{ Cointegrated } \\
\hline SSEE (TREV, NONTREV, PCGDPR) & & 3 & 4.10 & 2.79 & 3.67 \\
\hline \multicolumn{6}{|l|}{ Cointegrated } \\
\hline GOVEFF (TREV, NONTREV, PCGDPR) & 3 & 4.10 & 2.79 & 3.67 & \\
\hline Cointegrated & & & & & \\
\hline
\end{tabular}

Source: Researcher's compilation (2019)

Note: $\mathrm{K}=$ number of parameters

\subsection{The Results of Sources of Revenue and Provision of Health Care Equation}

The result is reported in Table 3. From the results and in consonance with the theoretical expectation, a negative relationship exists between earned or tax revenue (TREV) and provision of health care proxy by infant mortality rate (IMR) in Nigeria. The value of the coefficient of earned revenue (TREV) was -0.607 and was statistically significant with a probability value of 0.0101 (significant at about $1.01 \%$ level of significance). This implies that an increase in tax revenue by 1 percent can result to a decrease in infant mortality rate vis-à-vis improve health care by about 0.61 percent. Unearned or Non-tax revenue (NONTREV) had an expected positive sign in conformity with the theoretical expectations but was statistically insignificant. The magnitude of the coefficient of Non-tax revenue was 0.99683 with a probability value of 0.4024 (significant at $40.24 \%$ > required $10 \%$ level of significance). Hence, Non-tax revenue does not have a significant impact on provision of health care services in Nigeria. Thus, an increase in tax revenue (earned revenue) instigate improve in provision of health care, while increase in non-tax (unearned revenue) had no significant impact on provision of health care in Nigeria.

The effect of per capita GDP growth (PCGDPR) on infant mortality rate was negative at both current period and one year lagged, and was significant after one year lagged with a coefficient of -0.038828 and probability (prob.) value of 
0.0361. The result is in line with economic theory. Hence, an increase in per capita GDP growth by 1 percent will instigate a decrease in infant mortality by about $0.039 \%$ after a year.

The error correction mechanism (ECM) has the correct sign and size. The ECM coefficient of -0.0121 indicates that, it takes sluggishly only about 1.2 percent for the short run disequilibrium to adjust to the long run equilibrium within the year. The t-statistic of -2.80 shows that the error correction term is statistically significant at 5 percent level of significance.

The Adjusted R-squared of 0.64 indicates that about 64 percent of the total variations in infant mortality rate is explained by the independent variables, and about 36 percent was unexplained which may be accounted for by other factors not included in the model. The F-statistic of 15.02 about shows that all the variables in the model are together as a group statistically significant which means that the model has a moderate fit. Durbin-Watson (D-W) statistic of 1.97 is close to 2.00 and hence indicates no autocorrelation in the model. Therefore, the results can be used for economic forecast and policy simulation.

Table 3. Results of impact of sources of revenue on provision of health care (Dependent variable is IMR)

\begin{tabular}{lllll}
\hline Variable & Coefficient & Std. Error & t-Statistic & Prob.* $^{*}$ \\
\hline TREV & -0.607476 & 0.208113 & -2.918791 & 0.0101 \\
\hline NONTREV & 0.996837 & 1.140020 & 0.874403 & 0.4024 \\
\hline PCGDPR & -0.014527 & 0.014683 & -0.989346 & 0.3458 \\
\hline PCGDPR(-1) & -0.038828 & 0.016046 & -2.419821 & 0.0361 \\
\hline ECM(-1) & -0.012190 & 0.004350 & -2.802181 & 0.0187 \\
\hline R-squared & 0.800919 & Durbin-Watson stat & 1.978947 \\
\hline Adjusted R-squared & 0.641654 & & & \\
\hline F-statistic & 15.02885 & & & \\
\hline Prob(F-statistic) & 0.000197 & & & \\
\hline
\end{tabular}

Source: Researcher's compilation (2019)

\subsection{The Results of Sources of Revenue and Provision of Education Equation}

The results of the relative impact of tax revenue and non-tax revenue on provision of education proxy by secondary school education enrolment are reported in table 4. From the results both tax revenue and non-tax revenue had positive relationship with secondary school education enrolment (SSEE) in Nigeria. The value of the coefficient of tax revenue was 0.053 , and was significant at less than $1 \%$ level of significance given its probability value of 0.0012 . This implies that an increase in tax revenue by 1 percent will result to an increase in secondary school education enrolment by 0.053 percent. Implying that tax revenue has significant impact on secondary school education enrolment in Nigeria. Whereas, the magnitude of the coefficient of non-tax revenue was 0.046345 and was significant with probability value of 0.0007 . This shows that a 1 percent increase in non-tax revenue in the short run will lead to an increase of 0.046 percent in secondary school education enrolment in Nigeria. Hence, $1 \%$ increase in tax revenue had a greater impact on educational enrollment than a $1 \%$ increase in non-tax revenue.

The effect of per capita GDP growth (PCGDPR) on secondary school education enrolment was positive and significant with a coefficient of 0.245 and probability Value of 0.0007 . From the result of the study, an increase in per capita GDP growth by 1 percent will instigate a rise in secondary school education enrolment by 0.245 percent. The statistical significance of the variable indicates that; per capita income is an essential variable that affects secondary school education enrolment in Nigeria.

The error correction mechanism (ECM) has the correct sign and size. The ECM coefficient of -1.953 indicates that, it takes sluggishly only about 1.9 percent for the short run disequilibrium to adjust to the long run equilibrium within the year. The t-statistic of -5.447 shows that the error correction term is statistically significant at 5 percent level of significance. 
The R-squared value of 0.716 and the value of R-squared adjusted of 0.607 indicates that about 61 percent of the total variations in secondary school education enrolment is explained by the independent variables, and about 39 percent was unexplained which may be accounted for by other factors not included in the model. The F-statistic of 10.03 shows that all the variables in the model are together as a group statistically significant which means that the model has a moderate fit. Durbin-Watson (D-W) statistic of 2.19 indicates no autocorrelation in the model. Therefore, the results can be used for economic forecast and policy simulation.

Table 4. Results of impact of sources revenue on provision of education (Dependent variable: SSEE)

\begin{tabular}{lllll}
\hline Variable & Coefficient & Std. Error & t-Statistic & Prob. \\
\hline $\mathrm{D}($ TREV $)$ & 0.053249 & 0.011478 & 4.639350 & 0.0012 \\
\hline $\mathrm{D}($ NONTREV) & 0.046345 & 0.009220 & 5.026623 & 0.0007 \\
\hline $\mathrm{D}$ (PCGDPR) & 0.245630 & 0.079133 & 3.103996 & 0.0126 \\
\hline ECM(-1) & -1.953049 & 0.358546 & -5.447134 & 0.0004 \\
\cline { 1 - 2 } R-squared & 0.716588 & & \\
\cline { 1 - 2 } Adjusted R-squared & 0.607584 & & \\
\hline F-statistic & 10.03265 & & 2.190 \\
\hline Prob(F-statistic) & 0.000444 & Durbin-Watson Stat & \\
\hline
\end{tabular}

Source: Researcher's compilation (2019)

\subsection{The Results of Sources of Revenue and Government Effectiveness Equation}

The results of impact of Sources of Revenue on government effectiveness are reported in table 5. From table 5, a positive and significant relationship exists between tax revenue (TREV) and government effectiveness (GOVEFF) in Nigeria. The value of the coefficient of (0.009220) implies that an increase in tax revenue by $10 \%$ will result to an increase in government effectiveness by about $0.09 \%$. Whereas, non-tax revenue (NONTREV) as expected had a negative coefficient of -0.00400 (negative relationship) with government effectiveness and was statistically significant with a probability value of 0.0836 , implying significance at $8.36 \%$ level of significance. Therefore, as compared to tax revenue, a $10 \%$ increase in non-tax revenue will rather decrease government effectiveness by $0.04 \%$. Hence, the result is in consonance with existing prediction that tax revenue increases government effectiveness while increase in non-tax revenue reduces government effectiveness.

The long run effect of per capita GDP growth (PCGDPR) on government effectiveness was also positive. From the result of the study, an increase in per capita GDP growth by $10 \%$ will instigate a rise in government effectiveness by about $0.02 \%$ percent.

The error correction mechanism (ECM) has the correct sign and size. The ECM coefficient of -1.667218 indicates that, it takes about 1.7 percent for the short run disequilibrium to adjust to the long run equilibrium within the year. The t-statistic of -8.84 shows that the error correction term is statistically significant at 5 percent level of significance.

R-squared value of 0.940 and the value of R-squared adjusted of 0.866 indicates that about 87 percent of the total variations in government effectiveness is explained by the independent variables, and about 13 percent was unexplained which may be accounted for by other factors not included in the model. The F-statistic of about 12.68 shows that all the variables in the model are together as a group statistically significant which means that the model has a good fit. Durbin-Watson (D-W) statistic of 2.11 indicates no autocorrelation in the model. Therefore, the results can be used for economic forecast and policy simulation.

Table 5. Results of impact of sources revenue on government effectiveness index (Dependent variable: GOVEFF)

\begin{tabular}{lllll}
\hline Variable & Coefficient & Std. Error & t-Statistic & Prob. \\
\hline $\mathrm{D}($ TREV $)$ & 0.009220 & 0.004880 & 1.889344 & 0.0970 \\
\hline $\mathrm{D}($ NONTREV $)$ & -0.004000 & 0.002024 & -1.975825 & 0.0836 \\
\hline $\mathrm{D}($ PCGDPR $)$ & 0.002412 & 0.002102 & 1.147704 & 0.2843 \\
\hline
\end{tabular}




\begin{tabular}{llccc}
\hline ECM(-1) & -1.667218 & 0.188405 & -8.849120 & 0.0000 \\
\hline R-squared & 0.940671 & Durbin-Watson stat & & 2.113650 \\
\hline Adjusted R-squared & 0.866511 & & \\
\hline F-statistic & 12.68424 & & \\
\hline Prob(F-statistic) & 0.000714 & & & \\
\hline
\end{tabular}

Source: Researcher's compilation (2019)

\section{Discussion of Findings}

This study was carried out to test fiscal - social contract or the rentier state hypothesis, that states that rely upon earned income through taxes are more likely to become politically and institutionally effective. If a state relies mainly on unearned (none-tax) revenue, such a state is likely to be ineffective in provision of basic public goods and development of strong economic and political institutions. Findings showed that the hypothesis is valid and convincing in the context of Nigeria and that Nigeria is a rentier state.

Specifically, the results of the relative impact of tax revenue and non-tax revenue on provision of health care and education enrollment showed that, on one hand, an increase in tax revenue (earned revenue) instigates improve in provision of health care, while increase in non-tax (unearned revenue) had no significant impact on provision of health. On the other hand, a $1 \%$ increase in tax revenue had a greater impact on educational enrollment than a $1 \%$ increase in non-tax revenue. The result is in tandem with the findings of Martinez (2014), that the impact of a $\$ 1$ increase in tax revenue on educational enrollment was twice as large as the impact of a $\$ 4$ increase in non-tax revenues on educational enrollment in Colombia; and that of Gadenne (2014) who found that the quantity and quality of educational infrastructure in Brazilian municipalities is positively affected by local tax revenue while additional non-tax revenue have no effect; as well as Zhuravskaya (2000) who found that public good provision is better in Russian cities where increases in revenue are from taxes.

The results of impact of sources of revenue on government effectiveness is in consonance with existing prediction that tax revenue increases government effectiveness while increase in non-tax revenue reduces government effectiveness. The result agrees with the study of Adsera, Boix \& Payne (2003) that revenue from natural resource abundance can lead to a weakening of democratic institutions as well as economic ones.

The result also supports the findings of Moore (2014); Paler (2013); Self and Grabowski (2006); and Islam and Montenegro (2002), that political and economic institutions tend to be effective in countries that do not have significant revenue from natural resource endowments. That is, state effectiveness tends to be weaker in resource-rich countries where revenue is received and not earned. Specifically, States (the ruling elite) that rely upon earned income through taxes are more likely to become politically and institutionally effective. On the other hand, if the state relies mainly on unearned revenue (non-tax revenue) such a state is likely to be ineffective in development of strong economic and political institutions.

The findings also showed that, the effect of economic development proxy by per capita GDP growth on government effectiveness was positive and significant. The findings support Self and Grabowski (2006); and Lehne, et al (2014) that, rapidly growing countries and educated people are better able to afford better quality of institutions and effective state.

The overall findings strongly allied with the fact that indicators of state effectiveness like provision of basic public goods such as education and health which measures the wellbeing of the people as well as economic and political institutions have all deteriorated in most years since Nigeria began depending heavily on unearned revenue from oil, Hence Nigeria remains a rentier state.

\section{Conclusion}

The paper tested the fiscal - social contract or the rentier state hypothesis in Nigeria by examining the relative impact of earned (tax revenue) and unearned (non-tax revenue) revenues on indicators of state effectiveness in Nigeria from 1996-2018. Some empirical and theoretical literature was reviewed. Given that the variables were co-integrated of order zero and one, the equations were estimated using the autoregressive distributive lag (ARDL) co-integration technique. The paper found that, fiscal - social contract or the rentier state hypothesis is valid and convincing in the context of Nigeria. Specifically, on one hand, an increase in tax revenue (earned revenue) instigates improve in provision of health care, while increase in non-tax (unearned revenue) had no significant impact on provision of 
health. On the other hand, a $1 \%$ increase in tax revenue had a greater impact on educational enrollment than a $1 \%$ increase in non-tax revenue. Tax revenue increases government effectiveness while increase in non-tax revenue reduces government effectiveness. The paper concludes that, the effectiveness of Nigerian government in provision of basic public goods and development of strong economic and political institutions might improve if government increases their financial resources through earned revenues. This can be achieved by providing incentives and conducive business environment to the people in order to increase their economic activities, which in turn would broadening the tax revenue base and diversify the total tax revenue base away from mono-revenue/oil base. Increase in more people being taxed would increase the desire of the people in holding government accountable in the use of tax revenue and hence, improvement in the effectiveness of Nigerian state in the provision of basic public goods.

\section{References}

Adsera, A., Boix, C., \& Payne, M. (2003). Are you being served? Political accountability and governmental performance. Journal of Law, Economics and Organization, 19, 445-490. https://doi.org/10.1093/jleo/ewg017

Barro, J. R. (1999). Determinants of democracy. Journal of Political Economy, 107(6), 158-173. https://doi.org/10.1086/250107

Besley, T., \& Persson, T. (2011). The Logic of Political Violence. Quarterly Journal of Economics, 126(3), 1411-1445. https://doi.org/10.1093/qje/qjr025

Central Bank of Nigeria CBN. (2017). Statistical bulletin (various years). Abuja, Nigeria.

Collier, P. (1998). On the economic consequences of war. Oxford Economic Papers, 50, 168-183. https://doi.org/10.1093/oep/50.4.563

Dincecco, M. (2015). The rise of effective states in Europe. The Journal of Economic History, 3(75), 901-918. https://doi.org/10.1017/S002205071500114X

Easterly, W., \& Levine, R. (2003). Tropics, germs, and crops: how endowments influence economic development. Journal of Monetary Economics, 50, 3-39. https://doi.org/10.1016/S0304-3932(02)00200-3

Ebi, B. O. (2018). Financial sector development and tax revenue in Nigeria. International Journal of Economics, Commerce and Management, 6(6), 93-109.

Ebi, B. O., \& Aladejare, S. A. (2016). By how much will faster economic growth boost government revenue in Nigeria?. Journal of Economics and Development Studies, 4(2), 145-158.

Ebi, B. O., \& Ayodele, O. (2017). Tax reforms and tax yield in Nigeria. International Journal of Economics and Financial Issues, 7(3), 768-778.

Ebi, B. O., \& Ubi, P. S. (2016). Agricultural development and state effectiveness in Nigeria: a new rationale for increased capital accumulation in agriculture. Book of proceedings of the 17th Annual Conference of the Nigerian Association of Agricultural Economists Held at Federal University of Technology Owerri (FUTO), Nigeria (pp. 677-681).

Ebi, B. O., \& Ubi, P. S. (2017). Education expenditure and access to education: case study of United Nations educational, scientific and cultural organization declaration in Nigeria. International Journal of Economics and Financial Issues, 7(5), 290-298.

Ferejohn, J., \& Frances, R. (2010). War and state building in medieval Japan. Stanford University Press. https://doi.org/10.1515/9780804774314

Frankel, J. (2012). The natural resource curse: a survey. In B. Shaer, \& T. Ziyadov (Eds.), Beyond the resource curse. University of Pennsylvania Press, Philadelphia. https://doi.org/10.9783/9780812206173.17

Gadenne, L. (2014). Tax me, but spend wisely: sources of public finance and government accountability. Working Paper, University College London and Institute for Fiscal Studies.

Isham, J., Woolcock, M., Pritchett, L., \& Busby, G. (2005). The Varieties of Resource Experience: Natural Resource Export Structures and the Political Economy of Economic Growth. World Bank Economic Review, 19(2), 141-174. https://doi.org/10.1093/wber/lhi010

Islam, R., \& Montenegro, C. (2002). What determines the quality of institutions?. Background Paper for the World Development Report 2002. https://doi.org/10.1596/1813-9450-2764 
Lehne, J., Mo, J., \& Plekhanov, A. (2014). What determines the quality of economic institutions? Cross-country evidence. European Bank for Reconstruction and Development. W/P No. 171 . https://doi.org/10.2139/ssrn.3121122

Martinez, L. R. (2014). Sources of revenue and government performance: theory and evidence from Colombia. Department of Economics and STICERD, London School of Economics, Houghton London.

Moore, M. (2004). Revenues, state formation, and the quality of governance in developing countries. International Political Science Review, 3(25), 297-319. https://doi.org/10.1177/0192512104043018

National Bureau of Statistics (NBS). (2018). Multiple Indicator Cluster Survey 2016-17, Final Report. Abuja, Nigeria.

Paler, L. (2013). Keeping the public purse: An experiment in windfalls, taxes, and the incentives to restrain government. American Political Science Review, 107(4), 706-725. https://doi.org/10.1017/S0003055413000415

Ross, L. M. (2001). Does Oil Hinder Democracy?. World Politics, 53, 325-361. https://doi.org/10.1353/wp.2001.0011

Ross, L. M. (2004). Does taxation lead to representation?. British Journal of Political Science, 34(2), 229-249. https://doi.org/10.1017/S0007123404000031

Sala-Martin, R., Xavier, T., \& Subramanian, A. (2003). Addressing the Natural Resource Curse: An Illustration from Nigeria. IMF Working Paper No. WP/03. https://doi.org/10.3386/w9804

Self, S., \& Grabowski, R. (2006). Agricultural development, state effectiveness and long-run economic development. Journal of Economic Development, 73(2), 73-90.

Transparency International. (2019). Corruption perceptions. Retrieved from Index.http//www.transparency.org/policy research/surveys indices/CPI/2019

World Bank Group. (2018). The Worldwide Governance Indicators (WGI) project reports (2018).

World Bank. (2005). Building Effective States, Forging Engaged Societies. Report of the World Bank Task Force on Capacity Development in Africa, Washington, DC.

Zhuravskaya, E. V. (2000). Incentives to provide local public goods: fiscal federalism, Russian style. Journal of Public Economics, 76(3), 337-368. https://doi.org/10.1016/S0047-2727(99)00090-0

\section{Copyrights}

Copyright for this article is retained by the author(s), with first publication rights granted to the journal.

This is an open-access article distributed under the terms and conditions of the Creative Commons Attribution license (http://creativecommons.org/licenses/by/4.0/). 